\title{
Front Matter: Volume 11619
}

, "Front Matter: Volume 11619," Proc. SPIE 11619, Advanced Photonics in Urology, 1161901 (22 April 2021); doi: 10.1117/12.2596646

SPIE. Event: SPIE BiOS, 2021, Online Only 


\title{
PROGRESS IN BIOMEDICAL OPTICS AND IMAGING
}

\section{Advanced Photonics in Urology}

\author{
Hyun Wook Kang \\ Ronald Sroka \\ Editors
}

6-11 March 2021

Online Only, United States

Sponsored and Published by

SPIE 
The papers in this volume were part of the technical conference cited on the cover and title page. Papers were selected and subject to review by the editors and conference program committee. Some conference presentations may not be available for publication. Additional papers and presentation recordings may be available online in the SPIE Digital Library at SPIEDigitalLibrary.org.

The papers reflect the work and thoughts of the authors and are published herein as submitted. The publisher is not responsible for the validity of the information or for any outcomes resulting from reliance thereon.

Please use the following format to cite material from these proceedings:

Author(s), "Title of Paper," in Advanced Photonics in Urology, edited by Hyun Wook Kang, Ronald Sroka, Proc. of SPIE 11619, Seven-digit Article CID Number (DD/MM/YYYY); (DOI URL).

ISSN: 1605-7422

ISSN: 2410-9045 (electronic)

ISBN: 9781510640733

ISBN: 9781510640740 (electronic)

Published by

SPIE

P.O. Box 10, Bellingham, Washington 98227-0010 USA

Telephone +1 3606763290 (Pacific Time)

SPIE.org

Copyright (C) 2021 Society of Photo-Optical Instrumentation Engineers (SPIE).

Copying of material in this book for internal or personal use, or for the internal or personal use of specific clients, beyond the fair use provisions granted by the U.S. Copyright Law is authorized by SPIE subject to payment of fees. To obtain permission to use and share articles in this volume, visit Copyright Clearance Center at copyright.com. Other copying for republication, resale, advertising or promotion, or any form of systematic or multiple reproduction of any material in this book is prohibited except with permission in writing from the publisher.

Printed in the United States of America by Curran Associates, Inc., under license from SPIE.

Publication of record for individual papers is online in the SPIE Digital Library.

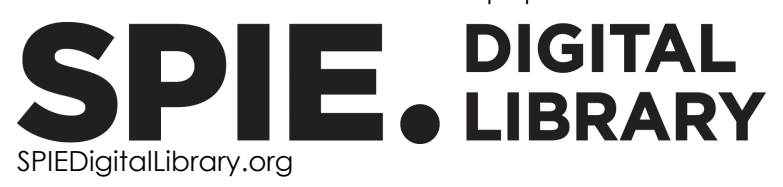

Paper Numbering: A unique citation identifier (CID) number is assigned to each article in the Proceedings of SPIE at the time of publication. Utilization of CIDs allows articles to be fully citable as soon as they are published online, and connects the same identifier to all online and print versions of the publication. SPIE uses a seven-digit CID article numbering system structured as follows:

- The first five digits correspond to the SPIE volume number.

- The last two digits indicate publication order within the volume using a Base 36 numbering system employing both numerals and letters. These two-number sets start with $00,01,02,03,04$, 05, 06, 07, 08, 09, OA, OB ... 0Z, followed by 10-1Z, 20-2Z, etc. The CID Number appears on each page of the manuscript. 


\section{Contents}

LASER LITHOTRIPSY I

1161908 Simulating manual manipulation of small optical fibers within flexible ureteroscopes for potential application in thulium fiber laser lithotripsy [11619-6]

OPTICAL IMAGING AND DIAGNOSIS II

$11619 \mathrm{OB} \quad$ A novel magnetic resonance imaging protocol to investigate how visual triggers impact urgency urinary incontinence [11619-9]

11619 OC A comparative in-vivo study of the female urethra with cross-polarization optical coherence tomography using two types of endoscopic probes [11619-10]

\section{LASER LITHOTRIPSY II}

11619 OD In-vitro investigations on improved laser lithotripsy using a diode pumped Im:YAG laser with a new temporal pulse regime [11619-11]

11619 OE The optimal dusting mode for Ho:YAG laser lithotripsy [11619-12]

11619 OF Characterization of a prototype miniature digital ureteroscope tip for enabling office-based thulium fiber laser lithotripsy [11619-13]

$116190 G$ Transient thermal simulation of lamp-pumped Ho:YAG laser [11619-14]

\section{POSTER SESSION}

11619 Ol Effects of laser power on laser fiber stiffness: momentum of photons [11619-16]

$116190 \mathrm{~J} \quad$ Laparoscopic optical coherence tomography system for 3D bladder fumor detection [11619-17] 
Proc. of SPIE Vol. 11619 1161901-4

\section{Downloaded From: https://www.spiedigitallibrary.org/conference-proceedings-of-spie on 25 Apr 2023
Terms of Use: https://www.spiedigitallibrary.org/terms-of-use}

